\title{
Investor's Reaction to Corporate Action Announcement: New Product and System and Technology Innovation
}

\author{
Juniarti Juniarti ${ }^{1, *}$ Novita Tenoyo ${ }^{1}$ Dea Devina Theja ${ }^{1}$ \\ ${ }^{1}$ Department of Business Accounting, Petra Christian University, Surabaya, Indonesia \\ *Corresponding author. Email: d12180241@john.petra.ac.id
}

\begin{abstract}
This study aims to know how investors react to corporate action announcements and to which categories that investors react more positively to. This study differs from previous studies because we use three different event windows to calculate CAR, which are $[+2,0,-2],[+1,0,+1],[-1,0]$. We also use firm size, market share, and market capitalization as control variables. Based on 201 samples in the period of 2020 by auto manufacturing firms in East Asia, we find that there is a significant difference of CAR between the firms that do and don't do corporate actions. Based on 148 corporate action announcements, we find that the new product category is responded more positively by investors than the system $\&$ technology innovation category. Besides that, we also find that firm size significantly affects investor's response, where large firms get more positive response from investors than small firms. The larger the size of the firm means that the firm has more resources and experiences, which give large firms more opportunities to successfully do corporate action. That reason makes investors interested to invest in large firms because they believe that large firms have better business prospects in the future. This study examines investor's response to corporate action announcements only in the automotive sector. Other sectors' results may differ from this study; therefore, future research has the opportunity to follow up on these issues.
\end{abstract}

Keywords: Corporate actions, Investor's response, New product, System and technology innovation, Cumulative abnormal return, Automotive sector.

\section{INTRODUCTION}

Financial Statements provide the basics to help investors acquire specific accounting information so that they are able to come up with an investment decision [1]; [2]. This shows that the financial reports done by the company are responded to by the investors because the investors are aware of any improvement on the company's financial performances which brings fundamental impact to the stock price [3]. However, most of companies' financial statements have lost its value relevance [4]; [3] ; [5]According to [6] it is due to the improvement in management's behavior towards discretionary reports and on non-earnings information used as the investors' assessment fundamental, which is often more punctual than financial statements. Due to the lost on value relevance, investors are becoming more motivated to look for new information [7] One of the examples of non-earnings information is in the form of a corporate action announcement. Corporate actions, such as a new product's launching and innovation on system and technology can be important information that will be noticed by the investors. This is due to the fact that news related to corporate actions can picture a company's business prospect.

A new product's launching often brings positive responses from investors [8]; [9]; [10];[11] This is due to the fact that a new product's launching is often seen as an important element for a company to escalate its long-term value [9] ; [12] A company publishes an announcement related to its product's development, hoping that investors would be aware of and respect the completed products' development efforts [13]. Besides launching a new product, an announcement of innovation on system and technology is also important to send signals to consumers and investors. An announcement takes an important role in building relations between companies and investors, in which an announcement of innovation on a company's system and technology can represent the 
idea that the company is in a stable condition and prepared to compete in a public market, convincing investors to invest in the company [12]. Thus supports the former research that investors tend to show their responses to news related to a company's system \& technology innovation which brings back positive abnormal returns to the company [3]; [14]; [15]; [16];[17];[18];[19] There are significant differences on investors' responses toward the system \& technology innovation category and new product category. This is due to the fact that investors are able to differentiate between good investment and poor investment [19], also because each investment category represents different value in the eyes of investors [20];[21];[22].

This study views the impact of corporate actions information towards investors' responses. There have been several former studies on multisector samples [3]; [14]; [15].Unlike the former research, this study is focusing on the automotive sector. The researchers choose to only focus on one sector in hopes that the study could bring out more accurate results. The researchers are aware of the fact that each industry has particular characteristics which differentiate one from another. The researchers focus on the automotive industry (auto manufacturer as the subsector) because the researchers consider it as a suitable subject for this study, emphasizing the idea that the automotive industry is very competitive in terms of launching new products [23]. Moreover, automotive companies continuously develop new innovations each year [24]. Furthermore, the advanced growth of technology has affected automotive companies to become more competitive to hold their place within the market.

In comparing the investors' responses, the researchers use data from two companies with comparable firm size. This is due to the fact that a company's total asset can represent its resources and influence its capability to compete within the market [25] therefore, particular small companies are more suitable compared to other small companies. This study also divides corporate actions into two categories based on its type and by observing the differences in investors' reactions during the time when corporate actions were taken into action and were not taken into action by a company.

Finally, this study contributes to the existing literature by providing a comprehensive research model related to corporate actions such as new product and system \& technology innovation. This study also see the differences of investor's response caused by different category of corporate action. This study directly complements the former study, by analyzed investors' responses toward companies who conduct corporate actions on auto manufacturer subsectors in East Asia with the use of several event windows in observing the impact of corporate actions' announcement day after day as a comparison [8]; [13]; [14]; [16].

\section{LITERATURE REVIEW \& HYPHOTHESIS DEVELOPMENT}

\subsection{Corporate actions}

Corporate actions refers to the act done by a company with the purpose of increasing investors' values through the shareholding ratio as a return to the investments they make. This causes fluctuations in the stock price by the time the company announces news related to the corporate actions [26]. A company often does several forms of corporate actions, such as new products and system \& technology innovation. Innovation is an important factor that can support a company in running its business, improving its competitiveness, as well as creating new products and markets [27]. In order to survive in the market, a company must be willing to do some changes to improve the firm value; those changes may include changes on its products, processes or services, which is known as innovation [28]. In this study, the intended innovation is the system \& technology innovation. Innovations done by a company could influence investors' and consumers' decisions. This is supported by the fact that a company often innovates to improve customer satisfaction. On the other hand, news related to corporate actions is considered as one of the fundamental measurements for investors before deciding on investing in a company, in which investors would have to review the impact of the intended innovation towards a company's future. Development of new products is often done by a company with the purpose of being able to compete in the market, which can also improve its value amongst investors and consumers [29]. Furthermore, the new products' development should convince investors of the fact that the company has motivations to innovate and opportunities to grow further in the future [30].

\subsection{Signalling Theory}

One way of a company to send signals to investors is through announcements related to corporate action. In sending signals to investors, a company has to consider the right timing so that it can perceive the idea that the company has better prospects and increase its firm value [30]Having a better future prospect would allow a company to reduce uncertainties from investors [31]. This can be a form of consideration for investors in making an investment. A company sends signals in order to make sure that the other parties have the same information about the company's current condition and avoid having information asymmetry, where one party has less information than the other [32]. In case the investors are able to translate the signal and the news related to corporate actions as an important aspect, the investors would show responses toward it [33]; [34]; [35] 
stated a company that has developed new products may send signals to investors related to its level of innovation. Corporate action's announcements passed by a company, in terms of developing new products and innovating on system \& technology can be seen as a positive signal by investors, which would bring advantages and escalate the company's value [14]; [16]; [34];[35].

\subsection{EMH (Efficient Market Hypothesis)}

Information shared throughout the efficient market can bring out abnormal returns, which is reflected on the stock price [35]. Changes on the stock price caused by receiving information or signals from a company reflects the idea that there are reactions on security markets [36]. A market is considered efficient when the stock prices entirely reflect all the available information [37]. In an efficient market, there is no difference in the amount of information received by each individual because everyone receives the same amount of information and acts rationally on it. Investors can use the existing information to project the company's future performances In an efficient market, investors are assumed to have access to all public information as well as the idea that time and sources of information do not measure up any values in the eyes of the investors, where only the content of the information is taken into consideration by the investors in making decisions [11]. The market would respond faster when there is new information related to the corporate actions done by a company [37]. Therefore, if the company is listed on stock exchange and involved in an efficient security market, then the company's announcement on corporate actions would directly be reflected on its stock price; thus enables the researchers to conduct a close examination on how the investors respond to the intended corporate action's announcement through the changes on its stock price [9]; [11]; [12]; [14]; [16]; [17]; [36].

\subsection{Hypothesis Development}

Companies who conduct corporate actions, such as on new products' development and system \& technology's innovation often get positive responses from investors. The development of new products does not only attract the attention of consumers and competitors, but also of the investors. Kempf found out that company's managers conduct corporate actions to attract the attention of investors, which could escalate its company's value. The development of new products creates an opportunity for a company to differentiate itself and acquire a competitive advantage; thus bringing positive impacts on a company's revenue and market value [8]. A company that conducts innovative development on its new products attracts investors' willingness to invest resulting in positive responses from investors. Investors consider companies who often conduct new products' development as having chances to grow and acquire better performances in the future .

Innovations, such as having big or small changes on a product, process and service benefits and elevates a company's value in the eyes of the customers [27]. Besides innovation on products, innovation on system and technology is also important to be considered by a company. Furthermore, innovation on system and technology provides signals to investors that the company has good prospects and is prepared to compete in the market [12]; [36]. If the innovation is seen as a good impact for the company's future, then investors would respond positively [14];[15]; [16]; [17]; [18]. Due to the growth of technology, specifically Artificial Intelligence (AI), robotics as well as augmented and virtual reality, a company needs to improve its productivity and chances to grow further by continuously innovating to be able to compete with other companies Innovations on systems or IT in the automotive sector can be in the form of producing applications to ease customers in conducting transactions, which would simultaneously bring positive impact to the company's value. Companies innovating on IT have more potential to gain more profits, which results in positive reactions from investors who hopes to gain sustainable earnings [14].

$\mathrm{H}_{1}$ : Corporate actions influences investors' responses in a positive way.

Investments made by companies in conducting corporate actions have different values in the eyes of investors; thus bringing out different responses. found that investors show different responses according to the type of investment announcement published by a company. found that there are differences of abnormal return in the investment done by a company, particularly in the R\&D and Product or Market categories. Dividing the types of investment into seven categories (Joint Venture, R\&D, Diversification, Expansion, New Plant, New Project, and Capital Expenditure), [21] also found differences in abnormal return in those seven types of investments. This is because of the fact that the market's reaction towards investment decisions depends on the quality of a company's investment opportunity [21]. Therefore, investors' reactions highly depend on the type of investment done by the company. [19] found that investors are able to differentiate good investment from a poor one, in which they tend to respond positively only to investments that allow a company to grow even better in the future. Investors respond negatively when they do not have enough trust toward a company's future prospect or in doubt whether the company is able to implement the investment project or not [22].

$\mathrm{H}_{2}$ : There are differences on investors' responses in each category of corporate action 


\section{METHOD}

\subsection{Model of Analysis}

The previous research uses cumulative abnormal return (CAR) to look further on how investors respond to an event [11]; [12]; [14]; [16]; [17]. This is conducted in order to determine whether there are changes on stock price by looking through the differences between actual return and expected return on a share. The researchers use some variable controls that can affect cumulative abnormal return (CAR), such as firm size, market capitalization, and market share. Meng \& Lee [16] found that firm size can influence the value of a company. Besides that, firm size can also influence return when a company announces its products' development [11]. Firm size becomes an important measurement to explain the variations of stock market responses [25]. The increasing numbers of competition within the industry could also influence the company's market share when introducing its new products, indicating that the more companies are introducing similar products the less increment there would be for each .Market share becomes one of the factors for investors in determining their decision. This is due to the fact that market share reflects a company's capability to innovate, which could hopefully bring profitable advantages in the future, as well as influencing the company's stock market. Lastly, market capitalization also becomes an important measurement for investors. This is due to the fact that market capitalization reflects the company's value, wealth and collective value or share.

\subsubsection{Model 1}

The first model is used to perceive if there are any significant CAR differences between a company that conducts corporate action and those that do not conduct corporate action, by using the DumCA as an independent variable, with the following equation of regression model:

$$
\begin{aligned}
& \text { CAR }_{\mathbf{i t}}={ }_{0}+{ }_{1} \text { DumCA }_{\mathrm{i}, \mathrm{t}}+{ }_{2} \mathrm{FIRM}_{\mathrm{i}, \mathrm{t}-1} \\
& +{ }_{3} \text { CAP }_{\mathrm{i}, \mathrm{t}-1}+{ }_{4} \text { SHARE }_{\mathrm{i}, \mathrm{t}-1}+{ }_{\mathrm{i}, \mathrm{t}}
\end{aligned}
$$

\subsubsection{Model 2}

The second model is used to perceive if there are any significant CAR differences between the system \& technology innovation and new products categories, by using DumCAC as the independent variable, with the following equation of regression model:

$$
\begin{aligned}
& \text { CAR }_{\mathrm{it}}={ }_{0}+{ }_{1} \text { DumCAC }_{\mathrm{i}, \mathrm{t}}+{ }_{2} \mathrm{FIRM}_{\mathrm{i}, \mathrm{t}-1} \\
& +{ }_{3} \text { CAP }_{\mathrm{i}, \mathrm{t}-1}+{ }_{4} \text { SHARE }_{\mathrm{i}, \mathrm{t}-1}+{ }_{\mathrm{i}, \mathrm{t}}
\end{aligned}
$$

\subsection{Variables operationalization}

\subsubsection{Dependent variable}

This study observes the investors' responses toward announcements related to the company's corporate actions by examining the CAR value in between the time the announcement is made. The researchers use stock prices during the 120 days of active trading with the event window $[-2,0,+2],[-1,0,+1]$ and $[-1,0]$. The researchers use a not-too-long event window to be right on target; thus would not be affected by other announcements and could cover the entire responses from investors on the days before and after the announcement. The researchers also count several CAR by using different event windows to compare investors' responses each day and examine the CAR on which event window would get mostly affected by the company's intended corporate action.

A corporate action announcement affects stock price. The effects can be in the form of cumulative abnormal returns (CAR) which is the sum of abnormal returns. Abnormal returns appear when an unexpected event happens on the stock market, in which every announcement published by a company can cause either positive or negative changes on the company's future cash flow [36]. Abnormal returns are the discrepancy between actual return and expected return. Abnormal returns are often used to indicate whether there is reaction in the trading market, which results in the existence of reaction's measurement in between the periods of announcement. If the corporate action's announcement involves good news for investors, then it would result in a positive abnormal return, reflected on the stock price in the market.

Firstly, the researchers count the actual return and expected return with the following formula:

$$
\begin{aligned}
& \mathbf{R}_{\mathbf{i t}}=\frac{P i t-P i t-1}{P i t-1} \\
& \mathbf{R}_{\mathbf{m t}}=\frac{I H S G t-I H S G t-1}{I H S G t-1}
\end{aligned}
$$

Evaluation on daily individual stock return regression with daily market return is carried out to obtain the value of $\alpha$ and $\beta$. The researchers use a few stock price indices in accordance to the origin of the studied company. A company in Japan uses the TOPIX index, Korea uses the KOSPI index, Taiwan uses the TWII index, Hong Kong uses the HSE index, and China uses the SSE index. Continuously, the daily expected return is counted with the following formula:

$$
\mathbf{E}\left(\mathbf{R}_{\text {it }}\right)=\alpha_{\mathrm{i}}+\beta_{\mathrm{i}} \times \mathrm{E}\left(\mathrm{R}_{\mathrm{mt}}\right)
$$

The researchers count abnormal return on the date when the company announces corporate action and in 
between the corporate action's announcement is made, with the following formula:

$$
\mathbf{A} \mathbf{R}_{\mathrm{it}}=\mathrm{R}_{\mathrm{it}}-\mathrm{E}\left(\mathrm{R}_{\mathrm{it}}\right)
$$

Furthermore, the researchers count the cumulative abnormal returns (CAR) by summing up daily abnormal returns for 2 days after, day 0 , and 2 days before for the event window $[-2,0,+2]$, then 1 day after, day 0 , and 1 day before for the event window $[-1,0,+1]$, lastly is day 0 and 1 day before for the event window $[-1,0]$, with the following formula:

$$
\boldsymbol{C} \boldsymbol{A} \boldsymbol{R}_{\mathrm{it}}=\sum_{t=-n}^{t=n} A R_{\mathrm{it}}
$$

\subsubsection{Independent variables:}

This study has two dummy variables that take the role as independent variables. The first dummy is DumCA, in which the number 0 represents the company who does not conduct corporate action, and the number 1 represents the company who conducts corporate action. The second dummy variable is DumCAC, used to differentiate the categories of corporate action announcements, in which the number 0 is used for the system \& technology innovation and the number 1 is for the new product.

\subsubsection{Control variables:}

\subsubsection{Firm Size}

Firm size (FIRM): is observed from the log value of the company's total asset [11]. The total asset from each company is then converted to US Dollar currency which is comparable and can provide valid results.

\subsubsection{Market Capitalization}

Market capitalization (CAP): is measured by using logarithm from the sum of share issued multiplied by the current stock price, then converted to US Dollar currency [17].

\subsubsection{Market Share}

Market share (SHARE): is measured from the company's total sales in US Dollar currency divided by the industry's total sales.

\subsection{Research Sample}

This study uses corporate action announcements from East Asian manufacturing companies. The researchers group the corporate action announcements into two categories, which are new product and system \& technology innovation (Table 1). The new product category includes all types of cars, motorcycles, trucks, and buses, whereas system \& technology innovation includes announcements related to innovations on system
$\&$ technology, which are used to increase the quality of the main product as well as the ones that are not related to the main product, including robots and applications. The chosen sample has to be within the following criteria:

\subsubsection{Main Sample}

1) The company needs to have a minimum of one announcement which is included in either the new product category or system \& technology innovation category, where the announcement for each category that becomes a sample cannot clash with one another, by having a minimum of 2 days before and 2 days after an announcement so that the differences on the stock price's effect in each category can be seen in more detail.

2) The announcement date must be within the year of 2020 .

3) The announcement related to corporate actions must come from the company's official websites or platforms (prioritizing the global website of each company).

4) The company must have valid daily data of share prices and data regarding shares as well as an annual financial report that includes important aspects such as total assets, total sales, and share issued.

\subsubsection{Control Sample}

1) The company who does not publish corporate action announcements must be within the same sub sector, which is auto manufacturers.

2) The company has a firm size which is comparable to other companies that publish corporate action announcements.

\section{RESULTS \& DISCUSSION}

There are at least 64 companies in the field of automotive manufacture in East Asia. However, the researchers cannot use all 64 companies as a sample because there are several auto manufacturing companies whose websites cannot be accessed by the researchers or do not have news section on their website. After the selection process, there are 40 companies that fulfill the researchers' criteria of sampling, in which 31 companies are used as the main sample while the other 9 as the control sample. The control samples act as a comparison (companies who do not announce news related to corporate actions in their company's websites).

Lastly, the researchers have acquired 201 data for this study. Within the aforementioned number, there are 148 data of do corporate action (CA), in which 41 of them are part of system \& technology innovation category, 107 data are part of the new product category, and the 
Table 1. Full Sample

\begin{tabular}{|c|c|c|c|}
\hline Corporate Action & Category & N & $\%$ \\
\hline \multirow{2}{*}{ CA (Do CA) } & System \& Technology Innovation & 41 & $20.40 \%$ \\
\hline & New Product & 107 & $52.23 \%$ \\
\hline \multicolumn{2}{|l|}{ NCA (Don't Do CA) } & 53 & $26.37 \%$ \\
\hline \multicolumn{2}{|l|}{ Total } & 201 & $100.00 \%$ \\
\hline
\end{tabular}

Table 2. Descriptive Statistics Full Sample

\begin{tabular}{|l|c|c|c|c|c|}
\hline \multirow{2}{*}{ Variable } & \multicolumn{5}{|c|}{ Full Sample (N=201) } \\
\cline { 2 - 5 } & Mean & Median & Max & Min & Std dev \\
\hline CAR $[-2,0,+2]$ & $0,52 \%$ & $0,46 \%$ & $13,27 \%$ & $-10,99 \%$ & $4,16 \%$ \\
\hline CAR $[-1,0,+1]$ & $0,72 \%$ & $0,46 \%$ & $12,75 \%$ & $-9,08 \%$ & $3,42 \%$ \\
\hline CAR $[-1,0]$ & $0,27 \%$ & $0,43 \%$ & $8,17 \%$ & $-8,66 \%$ & $2,82 \%$ \\
\hline FIRM & 10,0689 & 10,1698 & 11,6763 & 7,8318 & 0,8875 \\
\hline SHARE & 0,0307 & 0,0229 & 0,2230 & 0,0001 & 0,0498 \\
\hline CAP & 9,6037 & 9,6520 & 11,3006 & 7,9569 & 0,7120 \\
\hline
\end{tabular}

Table 3. Descriptive Statistics Per Corporate Action

\begin{tabular}{|l|c|c|c|c|c|c|c|c|c|c|}
\hline \multirow{2}{*}{ Variable } & \multicolumn{4}{|c|}{ Do Corporate Action (N=148) } & \multicolumn{5}{c|}{ Don't Do Corporate Action (N=53) } \\
\cline { 2 - 11 } & Mean & Median & Max & Min & Std dev & Mean & Median & Max & Min & Std dev \\
\hline CAR $[-2,0,+2]$ & $1,29 \%$ & $1,39 \%$ & $13,27 \%$ & $-8,81 \%$ & $4,09 \%$ & $-1,62 \%$ & $-1,76 \%$ & $7,03 \%$ & $-10,99 \%$ & $3,68 \%$ \\
\hline CAR $[-1,0,+1]$ & $1,38 \%$ & $1,06 \%$ & $12,75 \%$ & $-7,42 \%$ & $3,46 \%$ & $-1,12 \%$ & $-0,92 \%$ & $5,06 \%$ & $-9,08 \%$ & $2,56 \%$ \\
\hline CAR $[-1,0]$ & $0,75 \%$ & $0,83 \%$ & $8,17 \%$ & $-7,57 \%$ & $2,78 \%$ & $-1,06 \%$ & $-0,79 \%$ & $5,30 \%$ & $-8,66 \%$ & $2,50 \%$ \\
\hline FIRM & 10,2060 & 10,2875 & 11,6763 & 7,8318 & 0,9026 & 9,6859 & 10,0620 & 10,4418 & 7,9444 & 0,7237 \\
\hline SHARE & 0,0386 & 0,0124 & 0,2230 & 0,0001 & 0,5576 & 0,0084 & 0,0056 & 0,0255 & 0,0001 & 0,0085 \\
\hline CAP & 9,7601 & 9,8418 & 11,3006 & 7,9569 & 0,7347 & 9,1670 & 9,2918 & 9,6579 & 8,3186 & 0,3996 \\
\hline
\end{tabular}

Table 4. Descriptive Statistics Per Category

\begin{tabular}{|l|c|c|c|c|c|c|c|c|c|c|}
\hline \multirow{2}{*}{ Variable } & \multicolumn{3}{|c|}{ Category System \& Technology Innovation } & \multicolumn{5}{c|}{ Category New Product } \\
\cline { 2 - 11 } & Mean & Median & Max & Min & Std dev & Mean & Median & Max & Min & Std dev \\
\hline CAR $[-2,0,+2]$ & $0,07 \%$ & $0,23 \%$ & $8,85 \%$ & $-8,77 \%$ & $4,65 \%$ & $1,76 \%$ & $1,61 \%$ & $13,27 \%$ & $-8,81 \%$ & $3,78 \%$ \\
\hline CAR $[-1,0,+1]$ & $0,20 \%$ & $0,57 \%$ & $7,48 \%$ & $-6,04 \%$ & $3,40 \%$ & $1,82 \%$ & $1,43 \%$ & $12,75 \%$ & $-7,42 \%$ & $3,39 \%$ \\
\hline CAR $[-1,0]$ & $-0,22 \%$ & $0,26 \%$ & $5,50 \%$ & $-7,57 \%$ & $2,76 \%$ & $1,13 \%$ & $0,97 \%$ & $8,17 \%$ & $-5,78 \%$ & $2,70 \%$ \\
\hline FIRM & 10,4592 & 10,4473 & 11,6763 & 8,4159 & 0,7122 & 10,1090 & 10,1698 & 11,6763 & 7,8318 & 0,9508 \\
\hline SHARE & 0,0474 & 0,0155 & 0,2230 & 0,0004 & 0,0652 & 0,0353 & 0,0120 & 0,2230 & 0,0001 & 0,0516 \\
\hline CAP & 10,0104 & 10,0930 & 11,3006 & 8,6097 & 0,6385 & 9,6642 & 9,8418 & 11,3006 & 7,9569 & 0,7491 \\
\hline
\end{tabular}


Table 5. Correlations Model $1(\mathrm{~N}=201)$

\begin{tabular}{|c|c|c|c|c|c|c|c|}
\hline & CAR $[-2,0,+2]$ & CAR $[-1,0,+1]$ & CAR $[-1,0]$ & DumCA & FIRM & SHARE & CAP \\
\hline CAR $[-2,0,+2]$ & 1 & & & & & & \\
\hline $\operatorname{CAR}[-1,0,+1]$ & $\left.0,30911^{\star *}\right)$ & 1 & & & & & \\
\hline CAR $[-1,0]$ & $0,3219\left(^{\star \star}\right)$ & $\left.0,68822^{(* *}\right)$ & 1 & & & & \\
\hline DumCA & $0,2850^{(* *)}$ & $0,5369\left(^{* \star}\right)$ & $\left.0,7291^{(\star *}\right)$ & 1 & & & \\
\hline FIRM & $\left.0,2588^{(* \star}\right)$ & $0,2128\left(^{(\star *}\right)$ & 0,2693 (**) $^{*}$ & 0,2048 (**) $^{*}$ & 1 & & \\
\hline SHARE & $0,2681(\star \star)$ & $0,1448\left(^{(}\right)$ & $0,1781\left(^{*}\right)$ & $0,1536\left(^{*}\right)$ & $\left.0,7106^{(\star \star}\right)$ & 1 & \\
\hline CAP & $\left.0,3680^{(* *}\right)$ & $\left.0,2366^{(* \star}\right)$ & $0,2820\left(^{* \star}\right)$ & $\left.0,2190{ }^{(* *}\right)$ & $\left.0,90211^{\star \star *}\right)$ & $0,7009\left(^{(*}\right)$ & 1 \\
\hline
\end{tabular}

${ }^{*}=$ Correlation is significance at the 0,05 level (2-tailed)

$* *=$ Correlation is significance at the 0,001 level (2-tailed)

Table 6. Correlations Model $2(\mathrm{~N}=148)$

\begin{tabular}{|c|c|c|c|c|c|c|c|}
\hline & CAR $[-2,0,+2]$ & CAR $[-1,0,+1]$ & CAR $[-1,0]$ & DumCAC & FIRM & SHARE & CAP \\
\hline CAR $[-2,0,+2]$ & 1 & & & & & & \\
\hline CAR $[-1,0,+1]$ & $0,6960\left(^{* \star}\right)$ & 1 & & & & & \\
\hline CAR $[-1,0]$ & $0,5284\left(^{* *}\right)$ & $\left.0,7008{ }^{(\star \star}\right)$ & 1 & & & & \\
\hline DumCAC & $0,1862\left(^{\star}\right)$ & $0,2104\left(^{\star}\right)$ & $0,2170\left(^{* *}\right)$ & 1 & & & \\
\hline FIRM & 0,1544 & $\left.0,23333^{(*}\right)$ & $0,2003\left(^{*}\right)$ & $-0,1742\left(^{*}\right)$ & 1 & & \\
\hline SHARE & 0,0787 & 0,1072 & 0,1033 & $-0,0978$ & $0,7365(* *)$ & 1 & \\
\hline CAP & 0,1513 & $0,1929\left(^{*}\right)$ & 0,1558 & $-0,2116\left(^{(*}\right)$ & $0,9018\left(^{* \star}\right)$ & $\left.0,68622^{(*)}\right)$ & 1 \\
\hline
\end{tabular}

* = Correlation is significance at the 0,05 level (2-tailed)

$* *=$ Correlation is significance at the 0,001 level (2-tailed)

remaining 53 do not do corporate action (NCA). Table 2, Table 3, Table 4, Table 5 and Table 6 show the results of descriptive statistics of full sample, descriptive statistics per corporate action, descriptive statistic per category, the correlation model 1 and the correlation model 2, respectively

\subsection{Hypothesis Testing}

The main purpose of this study is to find empirical evidence that investors do respond to announcements related to corporate action done by a company. This study is quite different from many other researches, in which this study is trying to find out if there are any differences on investors' responses toward the corporate actions category (System \& Technology Innovation and New Product). This study also aims to calculate the CAR by using three event windows which will later be put in comparison. The three event windows are $[-2,0,+2],[-1$, $0,+1]$ and $[-1,0]$.

\subsubsection{Impact of corporate action announcement on Cumulative Abnormal Return}

The tested data come from 18 different companies ( 9 pairs), with a total of 106 data. There are 2 data categories from each event window. The first group consists of 53 CAR data which are influenced by corporate action announcements. The second group consists of 53 CAR data which are not influenced by corporate action announcements which act as the control sample or the comparing companies for this study. This researchers use paired samples t-test to test the hypothesis, in which before conducting the test, the data have to have normal distribution. The researchers do Kolmogorov-Smirnov normality test and finds that the significance value of $>0.05$ in each data group, meaning that the data have had normal distributions. Next, the researchers do paired sample t-tests toward each event window, where each event window has 2 groups of data, which are CA (conducting corporate action) and NCA (do not conduct corporate action). 
In Table 7, it is visible that the mean CAR value of the companies that conduct corporate action is $>$ than the mean CAR value of the companies that do not conduct corporate actions within the three event windows. In order to see if there are any significant differences between the two, it is possible to view them through the significance value in each event window. It is visible that CAR $[-2,0,+2],[-1,0,+1]$, and $[-1,0]$ have the significance value of $<0.001$ and the t-values $>\mathrm{t}$-table. So it can be concluded that the companies which conduct corporate action are responded positively by the investors, thus $\mathrm{H} 1$ is accepted. Between the three aforementioned event windows, the researchers find out that event window $[-1,0,+1]$ has the most significant impact compared to event window $[-2,0,+2]$ and $[-1,0]$, with the significance value of 0.000000068 and $t$-value of 6.0941 .

\subsubsection{Regression}

The researchers do a number of classic assumption tests toward the two sample groups with each consisting of 201 data and 148 data for three event windows which are, CAR $[-2,0,+2],[-1,0,+1]$, and $[-1,0]$. First, the researchers test the normality of the data within the two regression models using Kolmogorov-Smirnov. The significance value of the three event windows after the normality test is $>0.05$, which shows that both regression models have normal distributions. The researchers then also do a multicollinearity sample test resulting in the Tolerance of $>0,10$ and VIF $<10$. Therefore, it can be concluded that multicollinearity does not happen on the two regression models. The researchers also do heteroscedasticity tests by looking at the result of linear regression's scatter plot. The scatter plot does not form any patterns, and the data are spreading; thus, it can be concluded that heteroscedasticity does not happen to both regression models.

\subsubsection{Regression Model 1}

Firstly, the researchers do multiple linear regression tests for CAR $[-2,0,+2],[-1,0,+1]$, and $[-1,0]$ using all samples (the main and control samples) which are 201 sample data in total (Table 8). The researchers input control variables which can be seen in Table 9. The variable value of DumCA on the three event windows shows the significance value of $<0.05$. The positive $t$-stat value shows that companies with corporate action (DumCA=1) have more positive responses from the investors compared to companies that do not do corporate action (DumCA=0). The result is similar to the paired sample t-test with 106 data. All of control variables do not have significant impacts toward CAR with the significance value $>0.05$. According to the adjusted Rsquare coefficient, the DumCA variable and the three control variables simultaneously have impact on CAR value as much as $9.9 \%$ on event window $[-2,0,+2]$ in which the $90.1 \%$ are explained with other variables, $12.6 \%$ on event window $[-1,0,+1]$ in which $87.4 \%$ are explained by other variables, and $8,2 \%$ on event window $[-1,0]$, in which $91,8 \%$ are explained by other variables. From the three event windows, it is visible that CAR [-1, $0,+1]$ has the highest adjusted R-square value; this results show that the DumCA variable FIRM, SHARE, and CAP are the most reliable in explaining the impact towards CAR in event window $[-1,0,+1]$ (Table 9).

Table 7. Paired Samples T-Test

\begin{tabular}{|l|l|c|c|c|c|}
\hline \multirow{2}{*}{} & \multirow{2}{*}{ Corporate Action } & \multirow{2}{*}{$N$} & \multicolumn{2}{|c|}{ CAR } \\
\cline { 4 - 6 } & & & {$[-2,0,+2]$} & {$[-1,0,+1]$} & 0,0085 \\
\hline \multirow{2}{*}{ Mean } & CA (Do) & 53 & 0,0115 & 0,0136 & $-0,0106$ \\
\cline { 2 - 6 } & NCA (Don't Do) & 53 & $-0,0162$ & $-0,0112$ & 5,0367 \\
\hline T-stat & & 4,5231 & 6,0941 & $0,0000^{\star *}$ \\
\hline \multicolumn{2}{l|}{ Significance } & & $0,0000^{\star *}$ & $0,0000^{\star *}$ & \\
\hline
\end{tabular}

$*=$ significance level $<0,05$

$* *=$ significance level $<0,00$

Table 8. Sample of Regression Model 1

\begin{tabular}{|l|c|c|}
\hline Category & N & $\%$ \\
\hline CA (Do CA) & 148 & $73,63 \%$ \\
\hline NCA (Don't Do CA) & 53 & $26,37 \%$ \\
\hline Total & 201 & $100,00 \%$ \\
\hline
\end{tabular}


Table 9 Regression Model 1

\begin{tabular}{|l|c|c|c|c|c|c|c|c|c|}
\hline \multirow{2}{*}{ Variable } & \multicolumn{3}{|c}{ CAR [-2,0,+2] } & \multicolumn{3}{c|}{ CAR [-1,0,+1] } & \multicolumn{3}{c|}{ CAR [-1,0] } \\
\cline { 2 - 10 } & Coefficient & t-stat & Sig & Coefficient & t-stat & Sig & Coefficient & t-stat & Sig \\
\hline DumCA & 2,5324 & 3,6515 & $0,0000^{*}$ & 2,1058 & 3,7507 & $0,0000^{*}$ & 1,5902 & 3,3566 & $0,0000^{*}$ \\
\hline FIRM & 0,6106 & 0,7942 & 0,4281 & 0,8459 & 1,3590 & 0,1757 & 4,7200 & 0,8987 & 0,3699 \\
\hline SHARE & $-5,5711$ & $-0,6835$ & 0,4951 & $-5,3337$ & $-0,8084$ & 0,4199 & $-1,5581$ & $-0,2799$ & 0,7799 \\
\hline CAP & 0,3921 & 0,4023 & 0,6879 & 0,1853 & 0,2349 & 0,8145 & 0,0492 & 0,0739 & 0,9412 \\
\hline C & $-11,0845$ & $-2,1252$ & 0,0348 & $-10,9670$ & $-2,5974$ & 0,0101 & $-6,0730$ & $-1,7046$ & 0,0899 \\
\hline$R^{2}$ & 0,117 & & & 0,144 & & & 0,100 & & \\
\hline Adj. R2 & 0,099 & & & 0,126 & & & 0,082 & & \\
\hline F-stat & 6,489 & & & 8,215 & & & 5,444 & & \\
\hline N & 201 & & & & & & & & \\
\hline
\end{tabular}

Table 10 Sample of Regression Model 2

\begin{tabular}{|l|c|c|}
\hline Category & N & $\%$ \\
\hline System \& Technology Innovation & 41 & $27,70 \%$ \\
\hline New Product & 107 & $72,30 \%$ \\
\hline Total & 148 & $100,00 \%$ \\
\hline
\end{tabular}

Table 11 Regression Model 2

\begin{tabular}{|l|c|c|c|c|c|c|c|c|c|}
\hline \multirow{2}{*}{ Variable } & \multicolumn{3}{|c|}{ CAR $[-2,0,+2]$} & \multicolumn{3}{c|}{ CAR [-1,0,+1] } & \multicolumn{3}{c|}{ CAR [-1,0] } \\
\cline { 2 - 11 } & Coefficient & t-stat & Sig & Coefficient & t-stat & Sig & Coefficient & t-stat & Sig \\
\hline DumCAC & 2,1034 & 2,8044 & $0,0057^{*}$ & 2,0334 & 3,302 & $0,0012^{*}$ & 1,6139 & 3,228 & $0,0015^{*}$ \\
\hline FIRM & 0,6244 & 0,6877 & 0,4928 & 1,5126 & 2,029 & $0,0443^{*}$ & 1,1296 & 1,8665 & 0,0640 \\
\hline SHARE & $-7,2538$ & $-0,8294$ & 0,4082 & $-9,8545$ & $-1,3724$ & 0,1721 & $-5,5698$ & $-0,9554$ & 0,3410 \\
\hline CAP & 0,8006 & 0,7651 & 0,4455 & 0,0086 & 0,0100 & 0,9921 & $-0,1634$ & $-0,2343$ & 0,8151 \\
\hline C & $-14,1348$ & $-2,3065$ & $0,0225^{*}$ & $-15,2348$ & $-3,0278$ & $0,0029^{*}$ & $-10,1313$ & $-2,4801$ & $0,0143^{*}$ \\
\hline$R^{2}$ & 0,078 & & & 0,131 & & & 0,112 & & \\
\hline Adj. R & 0,052 & & & 0,107 & & & 0,087 & & \\
\hline F-stat & 3,034 & & & 5,387 & & & 4,502 & & \\
\hline N & 148 & & & & & & & & \\
\hline *= significance level $<0,05$ & & & & & & & & & \\
\hline
\end{tabular}

$* *=$ significance level $<0,00$ 


\subsubsection{Regression Model 2}

Next, the researchers do a second model of multiple linear regression test towards CAR $[-2,0,+2],[-1,0,+1]$, and $[-1,0]$ using all the main samples, which are 148 corporate action announcements (Table 10). The researchers inputs control variables whose results can be seen in Table 11. The variable value of DumCAC on the three event windows shows a significance value of $<0.05$, so it can be concluded that the differences on the corporate action category have a significant impact on the CAR value which means that the second hypothesis is accepted. The t-stat with positive value shows that the new product category (DumCAC $=1$ ) is responded more positively by investors compared to the system \& technology innovation category (DumCAC $=0$ ). Among the three control variables, it is only firm size that has significant impact on CAR, whereas market share and market capitalization do not have a significant impact on it. In conclusion, the size of the company has a significant impact towards the investors' responses whenever a company conducts corporate action. The positive value on t-stat shows that there is a positive correlation between the size of a company and its impact on CAR values. According to adjusted R-square coefficient, the DumCAC variable and the three control variables simultaneously have impact on CAR value as much as $5,2 \%$ on event window $[-2,0,+2]$ in which $94.8 \%$ are explained by other variables, $10.7 \%$ on event window [$1,0,+1]$ in which $89.3 \%$ are explained by other variables, and $8,7 \%$ on event window $[-1,0]$ in which $91.3 \%$ are explained by other variables. Among the three event windows, it can be seen that CAR $[-1,0,+1]$ has the highest adjusted $\mathrm{R}$-square value, which means that the DumCAC variable, FIRM, SHARE, and CAP are the most reliable in showing the impact towards CAR on event window $[-1,0,+1]$.

\subsection{Discussion}

This study examines investors' responses toward the corporate action announcement conducted by a company, or if there are any differences in the investors' responses regarding the different types of corporate actions. The result of this study shows that the investors have positive responses regarding the announcement of new product development and system \& technology innovation making the first hypothesis is accepted. This study supports the previous research stating that investors show positive responses toward new product development [8]; [9]; [10]; [11]; [12] and the advancement of system \& technology innovation [14]; [15]; [16]; [17]; [18]. The existence of positive abnormal return around the date of the announcements proves that the investors are responding toward the news related to corporate action. In an efficient market, information related to corporate action announcements will be responded fastly by investors [37]. According to the signaling theory, investors consider corporate action announcements as a positive signal from companies. Investors see the companies as promising and having future prospects, thus making the investors able to reduce any uncertainties [30]; [31].

Next, the researchers find differences in investors' responses toward the new product category and system \& technology innovation category. This result is very similar to the previous research which says that differences on the types of corporate actions caused variations on the investors' responses [20]; [21]; [22]. The launch of a new product is one of the important events for all companies [11]. This is due to the fact that products are among the most impactful factors in the company's revenues. The launch of a new product in the automotive industry receives more positive responses from the investors because this industry tends to be more competitive, because each product is specifically targeted to different segments of the society [23]; [24]. The above reasons enable news regarding new products to become more interesting for investors, customers, and competitors, so that the second hypothesis is accepted. This study finds that the CAR with the event window [$1,0,+1]$ has the biggest value of adjusted R-square, which means this event window is the best way to explain the impact of corporate action announcements, especially on new product launch and innovation towards investors' responses. This result shows a similar result to the previous research, in which Warren \& Sorescu [11] find that the investors respond positively toward the news regarding new product launches with the use event window $[-1,0,+1]$ considering the possibility of information leakage and delay in news posting. Nagm \& Kautz [17] also find out that news regarding system \& technology innovation, in this case being IT investment gain positive responses from the investors, where the CAR in event window $[-1,0,+1]$ is more significant compared to the use of longer event window such as $[-5$, $0,+5]$.

Between the used variables within the two regression models, the researchers find out that firm size has a significant impact towards investors' responses regarding corporate actions done by companies in regression model 2 . The researchers find out that the larger the firm size is, the more positive the investors' responses toward the companies that conduct corporate actions. Firm size indicates a company's ability to manage its resources in order to develop its new products and reduce the investor's uncertainty. Large firms usually have a large amount of resources, enabling the company to take benefit from launching the new products in order to increase their firm values [36]. This study also supports the previous findings that state large firms as first movers in the market understand what the consumers want so that companies can develop new products and innovation demanded by the market, thus increasing its firm value [38]. Investors respond positively toward corporate actions done by the companies, which is why 
the companies need to carefully plan the launch of new products and do more innovations so that the investors' responses would be more positive, and the companies are able to gain positive and maximum abnormal return. Companies also have to take careful look at the contents they put in the news related to corporate actions. Sharma, et al. [35] find that the signals given by the companies have a varied number of effectiveness. Therefore, the more specific the corporate action news is, the higher its effectiveness will be, thus decreasing the uncertainty investors have. In the end, investors will respond more positively toward the news related to corporate action with specific contents [11]; [39].

\section{CONCLUSION}

This study shows that corporate action in the form of system \& technology innovation as well as new product announcements gain positive response from the investors, reflected on the positive abnormal return towards companies that conduct corporate actions rather than the ones that do not conduct corporate actions. The above statements prove that investors receive positive signals from the companies, bringing out positive abnormal return in between the dates of the corporate action. Investors respond positively toward the intended announcements because they believe that the companies that actively do corporate actions have better business prospects. This is due to the fact that those companies are considered prepared for competition, thus the investors are potentially able to gain more profits in the future. Next, there are some significant differences between the responses in the category of the corporate actions, which means each category has different values in the eyes of the investors. In the automotive sector, especially the auto manufacturers subsector, it is found that the investors respond more positively toward new products compared to system \& technology innovation, because product development is very impactful toward the profit of a company. This study also finds that firm size can affect the investors' responses, in which bigger companies usually gain a more positive response when they conduct corporate actions. The above phenomenon happens because the investors consider large firms to be more powerful competitors in the market as well as having more experience in product development and innovation.

This study supports the previous researches which found that the news related to corporate actions gain positive responses from investors, and that the different types of corporate actions have impacts toward the different response from the investors. Besides that, this study also has a few limitations. First, this study is only limited to auto manufacturers' subsectors. The next research can conduct researches on subsectors within the automotive sector, such as auto parts subsector or sectors other than the automotive sector. Secondly, the researchers encounter difficulty in accessing some companies' websites so the researchers may missed some corporate action done by company, the researchers were only able to collect data from the companies' official websites considering the fact that the information from the official websites are the most reliable. The next research can extract data from other reliable websites. Third, the researchers only used two types of corporate action that is considered most suitable with the auto manufacturer subsector; the next research can test out other types of corporate actions. Lastly, this study used short-term event windows because the researchers considered that the aforementioned event window is more suitable for this particular research. The next research could use a longer term of event window to see the impact of corporate actions in the long run.

\section{AUTHORS' CONTRIBUTIONS}

$\mathrm{J}$ conceived the ideas and design of the study. NT and DDT did data collection, data analysis and interpretation. After analysis and interpretation completed, $\mathbf{J}$ gave critical revision, and finally approved the final version of the study and agree to be published.

\section{ACKNOWLEDGMENTS}

The researchers would like to express her gratitude to Mrs. Juniarti as the advisor of this study. The researchers also would like to express her gratitude toward her parents and friends who have always supported him/her in the process of this study. Lastly, the researchers would like to express her gratitude to Petra Christian University for the help in data collection of this particular study.

\section{REFERENCES}

[1] B. Badu and K. O. Appiah, "Value relevance of accounting information: An emerging country perspective," J. Account. Organ. Chang., vol. 14(4), pp. 473-491, 2018, doi: https://doi.org/10.1108/JAOC-07-2017-0064

[2] H. A, "Value relevance of alternative accounting performance measures: Australian evidence," Account. Res. J., vol. 23 (2), pp. 190-212, 2010, doi:

https://doi.org/10.1108/10309611011073269.

[3] A. H. Almagtomel and Z. F. Abbas, "Value relevance of financial performance measures: An empirical study," Int. J. Psychol., vol. 24(7), 2020.

[4] A. M.M, "Have financial statements lost their relevance? Empirical evidence from the frontier market of Kuwait," J. Adv. Manag. Res., vol. 13 (2), pp. 225-239, 2016, doi: https://doi.org/10.1108/JAMR-06-2015-0043. 
[5] S. Brown and T. L. K. Lo, "Use of R2 in accounting research: Measuring changes in value relevance over the last four decades," J. Account. Econ., vol. 28 (2), pp. 83-115, 1999, doi: https://doi.org/10.1016/S0165-4101(99)000233.

[6] S. G. Ryan and P. A. Zarowin, "Why has the contemporaneous linear returns-earnings relation declined?," Account. Rev., vol. 78(2), 2003.

[7] A. A.J, "On the value relevance argument: Do market participants place a premium on future prospects of the firm?," J. Financ. Report. Account., vol. 16(4), pp. 660-676, 2018, doi: https://doi.org/10.1108/JFRA-02-2017-0012.

[8] C. S.S, "Organizational form and the economic impact of corporate new product strategies," $J$. Bus. Financ. Account., vol. 35(1\&2), pp. 71-101, 2008, doi: https://doi.org/10.1111/j.14685957.2007.02058.x.

[9] K. Pauwels, R. J. Silva, S. Srinivasan, and D. M. Hanssens, "New products, sales promotions, and firm value: The case of the automobile industry," J. Mark., vol. 68(4), pp. 142-156, 2004, doi: https://doi.org/10.1509/jmkg.68.4.142.42724.

[10] M. B. Talay, M. B. Akdeniz, M. Obal, and J. D. Townsend, "Stock market reactions to new product launches in international markets: The moderating role of culture," J. Int. Mark., vol. 20(10), pp. 1-18, 2019, doi: https://doi.org/10.1177/1069031X19874789.

[11] M. Bornman and J. Wessels, "The role and dimensions of taxpayer commitment in tax compliance behaviour," eJournal Tax Res., vol. 15, n, pp. 506-531, 2017.

[12] C. P.K, T. M. Devinney, and R. S. Winer, "The impact of new product introductions on the market value of firms," J. Bus., vol. 64( 4), pp. 573-610, 1991, doi: https://doi.org/10.1086/296552.

[13] W. N.L, “A. Sorescu, When $1+1>2$ : How investors react to new product releases announced concurrently with other corporate news," J. Mark., vol. 81(2), pp. 64-82, 2017, doi: https://doi.org/10.1509/jm.15.0275.

[14] S. Rabino and T. E. Moore, "Managing newproduct announcements in the computer industry," Ind. Mark. Manag., vol. 18, pp. 35-43, 1989, doi: https://doi.org/10.1016/00198501(89)90019-9.

[15] B. Dehning, V. J. Richardson, and R. W. Zmud,
"The value relevance of announcements of transformational information technology investments," MIS Q., vol. 27(4), pp. 637-656, 2003, doi: https://doi.org/10.2307/30036551.

[16] D. Dobija, K. M. Klimczak, N. Roztocki, and H. R. Weistroffer, "Information technology investment announcements and market value in transition economies: Evidence from Warsaw Stock Exchange," J. Strateg. Inf. Syst., vol. 21(4), pp. 308-319, 2012, doi: https://doi/org/10.1016/j.jsis.2012.07.003.

[17] Z. Meng and S. Y. T. Lee, "The value of IT to firms in a developing country in the catch-up process: An empirical comparison of China and the United States," Decis. Support Syst., vol. 43, pp. 737-745, 2007, doi: https://doi.org/10.1016/j.dss.2006.12.007.

[18] F. Nagm and K. Kautz, "The market value impact of IT investment announcement: An event study," J. Inf. Technol. Theory Appl., vol. 9(3), pp. 61-79, 2008.

[19] A. Sood and G. J. Tellis, "Do Innovations really pay off? Total stock market returns to innovation," Mark. Sci., vol. 28(3), 2016, doi: https://doi.org/10.1287/mksc.1080.0407.

[20] S. S. Chen, T. . Chung, and L. . Chung, "Investment opportunities, free cash flow and stock valuation effects of corporate investments: The case of taiwanese investments in China," Rev. Quant. Financ. Account., vol. 16, pp. 299310, 2001, doi: https://doi.org/10.1023/A:1011270824166.

[21] E. JonesEuropean Journal of Financ, J. Danbol, and I. Hirst, "Company investment announcements and the market value of the firms," Eur. J. Financ., vol. 10(5), pp. 437-452, 2004, doi: https://doi/org/10.1080/1351847032000168696.

[22] P. Kaur and R. Kaur, "Effects of strategic investment decisions on value of firm: Evidence from India," Paradigm, vol. 23(1), pp. 1-19, 2019, doi: https://doi.org/10.1177/0971890719835442.

[23] J. . Woolridge and C. C. Snow, "Stock market reaction to strategic investment decisions," Strateg. Manag. J., vol. 11, pp. 353-363, 1990, doi: https://doi.org/10.1002/SMJ.4250110503.

[24] C. Droge, J. Jayaram, and S. K. Vickery, "The ability to minimize the timing of new product development and introduction: An examination of antecedent factors in the North American 
automobile supplier industry," J. Prod. Innov. Manag., vol. 17, pp. 24-40, 2000, doi: https://doi/org/10.1111/1540-5885.1710024.

[25] S. J, "Impact of new product announcements on stock prices (evidence from the Indian automobile industry)," Pacific Bus. Rev. Int., vol. 10, 2018, doi: https://doi.org/10.1177/0972150917713528.

[26] S. C. Chang, W. Y. WU, and Y. J. Wong, "Family control and stock market reactions to innovation announcements," Br. J. Manag., vol. 21, pp. 152-170, 2010, doi: https://doi.org/10.1111/j.14678551.2008.00618.x.

[27] T. Venkatesan and N. Rakesh, "Analysis of corporate actions and market efficiency in India," SJCC Manag. Res. Rev., vol. 8( 1), pp. 75-89, 2018.

[28] D. F. Kuratko, J. G. Covin, and J. S. Hornsby, "Why implementing corporate innovation is so difficult," Bus. Horiz., vol. 57(5), pp. 647-655, 2014 , doi: https://doi.org/10.1016/j.bushor.2014.05.007.

[29] S. L. Brown and K. M. Eisenhardt, "Product development: Past research, present findings, and future directions," Acad. Manag. Rev., vol. 20 ( 2), pp. 343-378, 1995, doi: https://doi.org/10.2307/258850.

[30] T. X. Li and Wang, "Investor reaction to R\&D investment: Are new product announcements and development capacity missing links? International," J. Innov. Sci., vol. 8(2), pp. 133147, 2016, doi: https://doi.org/10.1108/IJIS-062016-009.

[31] E. Morellec and N. Schurhoff, "Corporate investment and financing under asymmetric information," J. financ. econ., vol. 99(2) 2011, 2011, doi: https://doi.org/10.1016/j.jfineco.2010.09.003.

[32] D. D. Bergh, B. L. Conelly, D. J. K. Junior, and L. M. Shannon, "Signalling theory and equilibrium in strategic management research: An assessment and a research agenda," J. Manag. Stud., vol. 51( 8), pp. 1334-1360, 2014, doi: https://doi.org/10.1111/joms.12097.

[33] B. L. Connelly, S. T. Certo, R. D. Ireland, and C. R. Reutzel, "Signaling theory: A review and assessment," J. Manage., vol. 37(1), pp. 39-67, 2010 , doi: https://doi.org/10.1177/0149206310388419.
[34] N. H. Abdullah, R. A. Rashid, and Y. Ibrahim, "The effect of dividend announcements on stock returns for companies listed on the main board of the Kuala Lumpur Stock Exchange," Malaysian Manag. J., vol. 6(1\&2) 200, pp. 81-98, 2002, doi: $\quad$ https://doi.org/10.32890/mmj.6.12.2002.8598.

[35] R. P. Lee and Q. Chen, "The immediate impact of new product introductions on stock price: The role of firm resources and size," J. Prod. Innov. Manag., vol. 26(1), pp. 97-107, 2009, doi: https://doi.org/10.1016/j.bushor.2014.05.007.

[36] N. Marisetty and P. Madasu, "Corporate announcements and market efficiency: A case on indian capital market," Int. J. Bus. Manag., vol. 16( 8), doi: https://10.5539/ijbm.v16n8p71.

[37] K. R.A, "The efficient market hypothesis and accounting data: A point of view," Account. Rev., vol. 47( 4), pp. 791-793, 1972.

[38] R. A. Kerin, P. R. Varadarajan, and R. A. Peterson, "First-mover advantage: A synthesis, conceptual framework, and research propositions," J. Mark., vol. 56( 4), pp. 33-52, 1992, doi: https://doi.org/10.2307/1251985.

[39] A. Sorescu, V. Shankar, and T. Kushwana, "New product preannouncements and shareholder value: Don't make promises you can't keep," $J$. Mark. Res., vol. 44, pp. 468-489, 2007, doi: https://doi.org/10.1509/jmkr.44.3.468. 